ながらも着実に行われていることが判明した。

（2）尿路変向術の変遷：演者が1967年に国立病院に 着任した頃，マンパワー不足と子宮癌における尿路救 済が多かったため，無力テーテル㽷管㾞を工大し，尿 路変向の90\%に行った。1973年に福岡大学に移り，膀 胱癌の増加とともに回腸導管（56\%）に主力が移り， 尿管瘻44\%となった. 1986年からは腸管 reservoir を 選択肢の 1 つとして採用し，個々の患者にふさわしい 術式を選ぶように努めた。最近 3 年では回腸導管が約 $70 \%$ ，尿管瘻と reservoir がそれぞれ $15 \%$ 程度の割合 となっている.

これまでに福岡大学では無カテーテル尿管㾞を 102 例経験した。片側手術が $61 \%$ ，両側が39\%であった。 両側の場合 QOL 向上のための single stoma 法をその $69 \%$ に行っている.

（3）無力テーテル法の術式と氺管の状態：われわれ は尿管反転乳頭法を行っているが, stoma 形成の成否 は尿管の血流や組織治癒力にかかっており，大量の照 射療法を受けた尿管は条件が悪い. $60 \mathrm{~Gy}$ 以上の照射 例では 3 分の 2 に stoma の壊死や狭窄が発生し, 力テ 留置が必要となった。しかし，照射なし例では $80 \%$ に tubeless 尿管瘦に成功した. Stoma の壊死を防ぐ方法 として 2 段階形成法も考案したが, 最近は行っていな w.

Tubelessにするための stoma 形成法として乳頭 法, 2 分弁法, $Z$ 形成法などがあるが, 実際問題として の大差はないと思われる.大切な共通点はストーマ形 成に際し尿管の漿膜面を絶対に外に露出させない点で あろう。

（4）両側尿管瘦における single stoma 法：第 1 法 はY字型に尿管を吻合する transureteroureterostomyで, 8 例に行い 6 例に成功した。本法では stoma の生着が確実で, 狭窄の心配のない慢性の拡張肥厚の ある尿管を stoma 側に選ぶことが成功の絶対条件で ある。実例として最長19年の成功例と失敗の 1 例を供 覽した. 左右とも正常尿管の症例は本術式の禁忌とす ベきである.

第 2 に左右の㽷管末端を $\mathrm{V}$ 字型に吻合して口径を 広げ， Z皮弁と組み合わせて flush stoma を作る広川 法 (conjoined method) を紹介した。広川氏は膀胱癌 全摘48例，その他 1 例に本法を行い，11年に及ぶ長期 観察で, 狭窄 2 例, 水腎 4 例ほかわずかな合併症を認 めているが，きわめて優秀な成績である。

第 3 に, double barrel 法の自験例について紹介し
た.膀胱癌全摘例が主な対象で18例に行い, 13例 (72\%) に成功した。失敗してカテ留置になったもの 5 例で あったが，慎重に㽷管周囲組織を保存し，緊張や絞扼 のない尿管瘦を丁寧に作ればほぼ間違いなく成功する ことが判明した.Single stoma 実現のためのV吻合術 式と double barrel 法は，左右とも正常尿管の場合に 良い方法である。ただし，短過ぎる尿管や，著しい肥 満者には施行が困難な場合がある。

（5）尿管瘻の長期成績：tubelessになし得た80例に おける無力テ維持率は，10年で $80 \%$ ，最長 24 年で53\% であった，維持不能となった原因は，照射療法に起因 する 8 例の狭窄を含めストーマの狭窄が11例，その他 の原因 5 例であった。

（6）尿管瘻の適応決定：迷うことなく first choice にすべきものは，単腎で尿管が拡張している場合であ る、腸管利用が不適当，すなわち腎機能が血清クレア チニン $2 \mathrm{mg} / \mathrm{dl}$ を越える場合や，年齿全，身状態，期待 余命に問題がある場合もよい適応である，膀胱全摘後 の尿路変向法の選択で, 他の術式と比較検討し尿管瘻 を選ぶ「慎重派」の考え方と，迷わずに尿管瘻を選ぶ 「積極派」の考え方とがあるが，どちらでも信念を持っ て選択することが大切である。

（7）まとめ：尿管瘦は第一線病院において低然信頼 されており，20\%程度に実施されている，安全で手術 侵襲が小さいこと，高齢者でも腎機能障害があっても 施行可能で, 術後合併症や再手術が少ないことは長所 として大きく評価してよい.

ただしQOLを考え，カテーテルの要らない方法， single stoma 法の実現を目指すべきである。手術に際 しては，「尿管血流の慎重な保存」と，絶対に成功させ る「執念」が大切である。

回腸導管：上田豊史（九州大）回腸導管における 第 1 の問題点として, 手術手技上重要である。1）ス トーマ形成，2）回腸・回腸吻合，3）尿管・回腸吻合 について，1993年 8 月唐津で開催された尿路変向術研 究会に参加した30名の医師によるアンケート結果と手 術手技に関連した合併症とその予防および対策につい て教室の成績を報告する。第 2 の問題点として，長期 経過例における上部尿路合併症の原因と対策および腎 症痕形成について報告する。

I. 手術手技上の問題点

1. ストーマ形成

ストーマの位置については，腹直筋内が $57 \%$ と最も 高い回答率であったが，特にこだわらないという回答 
も27\%であった，腹壁口形成において，筋腹の処理は 円形切除 $50 \%$, 十字切開 $43 \%$ とほほ同じ回答率であり, 筋層の処理では鈍的開大が $73 \%$ と最も多く行われてい る。導管腹壁固定法として, 腹膜 - 筋層・筋膜一括と 皮膚の 2 層固定が50\%であるが，我々はパラストーマ ヘルニヤ予防のため， 3 層を別固定している．ストー マタイプとしては, $80 \%$ が乳頭状, End stoma を選別 しており, Loop stoma はわずか $7 \%$ ばある.ストーマ に関する合併症発生率は, 124 例中, 全体で 7 例 (5.6\%) であり, 年代別では, 頻度に大きな差はみられず, 最 近 7 年間の 38 例中 2 例 (5.3\%) にパラストーマヘルニ アがみられた。

2. 回腸・回腸吻合

回腸・回腸吻合における吻合法は Albert-Lembert の 2 層縫合が $67 \%$ と最も高い回答率であったが, 自動 縫合器使用も $17 \%$ にみられた，腸・腸吻合に関する合 併症発生率は, 全体で11例 (8.9\%) であり, 年代別で は, 頻度に差はなかったが, 最近自動縫合器を使用し た 1 例に腸㾇を認めた。

3. 尿管・回腸吻合

尿管・回腸吻合に際して，70\%の人が尿管屈曲や捻 れに対して, 何らかの工夫をしているが, 基本的には, 尿管の長さを必要最小限にすること, 左尿管を屈曲し ないようにうまく引き込むことが重要と考える. 術後 スプリント留置の功罪については, 一定の見解はない が, 我々は, 術後における尿管・腸吻合部の安静保持 の目的でスプリントカテーテルを術後 7〜10日留置し ている，吻合法としては，77\%が尿管・回腸全層直接 吻合であるNesbit 法を選択して抢り, 我々もこの吻 合法を行っている，尿管・腸吻合に関する合併症発生 率は, 全体で15例 $(12.1 \%)$ と, 他の合併症に比較し て, 高い頻度であった。年代別では, 最近 7 年間の頻 度は減少してきている，吻合部狭窄は種々の原因に よって発生するが, その予防として基本的には, 尿管 断端の処理, 操作を丁寧に行うことが大切である. 治 療法の選択は, 臨床上苦慮する所であるが, 我々はバ ルーン拡張術を行っているが満足する結果は得られて いない現状である。

II. 長期経過例の問題点一上部尿路合併症一

術後 5 年以上経過観察しえた51例を対象とした上部 尿路合併症の頻度は，腎盂腎炎 $15.7 \%$, 結石 $13.7 \%$, 水腎症 $23.5 \%$ であり, 長期的には上部尿路合併症は少 なからず発生するといえる. 水腎症の発現時期は術後 $1 \sim 5$ 年に最も多く, 5 年以上経過後にも 3 腎みられ
た. 結石の患側に差はなく, 発現時期は, 術後 $2 \sim 5$ 年が最も多く, 治療法としては, ESWLおよび内視鏡 的操作に対処しえている.

長期的にみて上部尿路に少なからず合併症が発生す る事実より，腎実質におよほす影響について，CT 所見 よりみた腎瘢痕の形成について検討した。対象例は術 後 2 年以上経過した 30 例，54腎であるが，術後腎洀痕 形成例は 7 例 (23.3\%)，9 腎(16.7\%)であり, Grade はII-5腎, III-3腎, IV-1腎であった。腎瘢痕形成例はす べて術後 9 年以上経過例であり，5例に何らかの上部 尿路合併症の頻度があったが，2例は原因不明であっ た. 腎孟造影で 6 例に腎杯変形, 蛋白尿は全例に認め られたが，クレアチニンレベルでの腎機能障害は 1 例 $(1.4 \mathrm{mg} / \mathrm{dl})$ のみであった。

まとめ

回腸導管は手術手技的には，ほほ確立された方法で あるが，各々術者自身による工夫もなされている，し かし，基本的にはストーマ形成，尿管・回腸吻合にお ける慎重な操作が大切である。一方, 長期経過例にお いては, 上部尿路合併症が少なからず発生し, subclinical な腎実質障害の原因となっている.しかし, 全 く上部尿路合併症の存在しない例に扮いても同様な所 見がみられており，その原因究明は今後の課題と考元 る.

\section{KOCK パウチ：岡田清己（日本大）}

1.はじめに

最近, 尿禁制尿路変向術が行われ, 今までの尿路変 向に伴う久点を抢ぎなう努力がなされてきた．最初に おこなわれたのがコックパウチである。これは腹壁に ストーマを作り，ここより間欠的導尿を行う方法であ る.この方法で術後患者のQOL はかなり改善したが, これで決して満足すべき結果ではなかった。すなわち ストーマのない，自然排尿に近い例にすることがのぞ まれた。これで登場したのがコックパウチを尿道に吻 合する尿道コックパウチである.

今回，われわれは長期間観察したとき，導尿型コッ クパウチ (CKP) と排尿型コックパウチ (UKP) がど のように機能しているかを検討し，あわせてそれらの 患者の QOL がどの程度であるかを調査したので発表 する.

\section{2. 症例}

過去 9 年間に導尿式コックパウチ (CKP) を 52 人に 行った。観察期間は 1 年から 9 年間にわたった。また, 排尿式コックパウチ (KUP) は41人に行い, 現時点で 